\title{
VIEWS OF WESTERN COUNTRIES ON THE 1926 COUP D'ÉTAT IN LITHUANIA
}

\author{
Algimantas Kasparavičius
}

ABSTRACT The analysis and evaluation of the 17 December 1926 coup d'état in Lithuanian historical scholarship to a large extent remain a relevant and controversial problem. The authoritarian regime formed after the coup has received various, yet not always well-grounded, descriptions and evaluations in historical writings. The aim of this article is (without attempting to answer at once all the questions pertaining to this issue) to tackle this problem from a different angle and as if from a distance, namely to analyse the political-diplomatic reaction to the coup d'état in Lithuania of the parties, which were not directly interested (foreign states).

On the one hand, the majority of democratic governments in Europe and the US administration had at least reserved and unopposed, if not favourable, view of the events of the 17 December 1926 in Lithuania. On the other hand, public, labour professional organisations and a part of the media in a number of foreign democracies were critical about the unconstitutional change of the government in Lithuania and the dictatorial domestic policy of the government formed on authoritarian grounds. Thirdly, in the eyes of liberal and democratic citizens or societies of the Western Europe the 1926 coup impaired the international prestige of Lithuania since it prompted doubts over the democratic traditions of the young state, the maturity of its social and political culture as well as prospects of maintaining its statehood.

The Lithuanian political conjuncture of recent decades has determined that the coup d'état of 17 December 1926 has continued to be quite a controversial and relevant problem in Lithuanian scholarship during the twentieth century. The authoritarian regime formed after the coup has received various, yet not always well-grounded evaluations. ${ }^{1}$ An overly exalted view of the coup is mostly typical of some historical

${ }^{1}$ I. Tamošaitis, 'Nuo gruodžio mèn. 17 d. ligi šių dienų', Pirmasis Nepriklausomos Lietuvos dešimtmetis (Kaunas, 1930); A. Kernius-Kernauskas, 1926-1929 gruodžio mèn. 17 d. istorinès Lietuvai dienos trimečio sukaktuvems paminèti (Kaunas, 1929); 1926-1936 gruodžio 17-osios dešimtmetis. Istorinès Lietuvai dienos sukaktuvèms pamineti (Kaunas, 1936); V. Skorupskis, La Resurrection d'un peuple 1918-1927 (Paris, 1930). 
and para-historical texts written by Lithuanian emigrants. ${ }^{2}$ Subjective criticism of the coup d'état or apologetics abound in the fairly prolific memoir literature on the issue. ${ }^{3}$ During the Soviet period this historical event was subject to even more ideology and mostly unreasonably, without any substantial arguments interpreted as profascist or even fascist. ${ }^{4}$ However, a part of the Lithuanian public holding patriotic and anti-Soviet views privately opposed such tendencies in evaluations made by historians controlled by the totalitarian authorities and attempted vaguely to qualify the coup d'état of 17 December 1926 as a more appealing nationalistic event and to some extent to integrate it into the heroics of resistance to sovietisation. Under such circumstances, a far from unambiguous or even twisted image of the coup formed in the mind of Lithuanians.

Thus, the aim of this article is (without attempting to answer at once all the questions pertaining to this issue) to tackle this problem from a different angle and as if from a distance, namely to analyse the political-diplomatic reaction to the coup from parties, which had no direct interest in it (foreign states). We believe that such angle of the study might prompt Lithuanian scholarship to abandon some of the myths or outright stereotypes directly related to this issue and expand the perspective of the problem for broader discussion.

In the early morning of 17 December 1926 (around 2-3 a.m.) the military in Lithuania revolted and broke up the parliament of the country, the Seimas; the rebels isolated and forced the left-of-cen-

2 J. Švoba, Seiminè ir prezidentine Lietuva (Chicago, 1985); A. Merkelis, Antanas Smetona. Jo visuomenine, kultūrine ir politinè veikla (New York, 1964); P. Maldeikis, Mykolas Krupavičius (Chicago, 1975); P. Jurgèla, Generolas Povilas Plechavičius (Brooklyn, 1978).

${ }^{3}$ K. Škirpa, 'Pakeliui su Mykolu Sleževičiumi', Mykolas Sleževičius (Chicago, 1954); 'Tautininkai ir gruodžio 17. Dr. K. Grinius apie 1926 m. perversmą (J. Kėdainio pasikalbejjimas su K. Griniumi)', Naujienos, 29 June 1951 - 19 July; Bronius Kazys Balutis, Jo gyvenimas ir darbai (Chicago, 1951); M. Krupavičius, '1926 metu gruodžio 17 d. (liūdna 30 metu sukaktis)’ Draugas, 26 Nov. 1956-14 Jan. 1957; R. Skipitis, Nepriklausomq Lietuvq statant. Atsiminimai (Chicago, 1961); V. Šliogeris, Antanas Smetona. Žmogus ir valstybininkas. Atsiminimai (Chicago, 1966); S. Raštikis, Kovose dèl Lietuvos (Los Angeles, 1956). vol. 1; S. Kairys, Tau Lietuva (Boston, 1964).

${ }^{4}$ E. Dirvelè, Klasiu kova Lietuvoje 1926 metais (Vilnius, 1961); idem, 'Liaudininkų ir socialdemokratu valdymas. Fašistinis perversmas Lietuvoje 1926 m.', Lietuvos TSR istorija (Vilnius, 1965). vol. 3; V. Kapsukas, Buržuaziné Lietuva (Vilnius, 1961); A. Gaigalaite, S. Noreikienè, 'Partijos liaudininkų ir socialdemokratu valdymo laikotarpiu', Klasès ir politinés partijos Lietuvoje (Vilnius, 1978); I. Lempertas, Fašistinis režimas Lietuvoje (Vilnius, 1975). 
tre coalition government of the Peasant Popular Union and Social Democrats to resign. The headquarters of the coup participants established in the Ministry of Defence announced that 'the coup d'état was effected exclusively by one army which was forced to do the same due to the Polonisation of the country and the pro-Bolshevik policy pursued by the government [...] which was a real threat to existence of the state'. ${ }^{5}$ Already on 17 December President Kazys Grinius succumbed to the pressure of the military who had effected the coup d'état and actually against his own will appointed Augustas Voldemaras, a professor of history who was close to the nationalist ideology of the takeover supporters and was an influential activist of the nationalists, as the new head of the government. Yet as it appeared shortly, such a division of power which manifested in the president's complaisance and only a partial transfer of the executive government to the coup d'état participants did not satisfy the latter. They required the total control of the state. Therefore, in the evening of the following day after lengthy persuasions as well as political and moral pressure, the liberal President Kazys Grinius, who had been elected democratically, was forced to resign. At the bidding of the coup participants and votes of the parties who rendered them political support (Christian Democrats and Nationalists) as well as national minorities, in the afternoon of 19 december 1926 the Third Seimas elected its member, an associated professor of the Faculty of Humanities of Kaunas University, the nationalist leader, lawyer, Antanas Smetona, as Lithuania's new president. The appointment of A. Voldemaras prime minister and the election of A. Smetona president virtually meant that the coup supporters managed in merely three days to 'legitimate' themselves quite easily and take over the whole pyramid of the executive government.

A retrospective view at the first steps of the authoritarian government reveals an interesting fact that the so-called formal 'legitimation' ${ }^{6}$ of the said regime in Lithuania was declaratively public and conducted as a well-organised public relations campaign. Moreover, there had been some advance preparations. Already on 18 December the leaders of the pro-government paper, Lietuva were replaced: Kazimieras Jokantas, an activist of the Farmers Association,

\footnotetext{
${ }^{5}$ Statement of the Ministry of Defence of Lithuania dated 18 December 1926 (Lithuanian National Martynas Mažvydas Library. Manuscript Department (henceforth LNMMB RS), f. 157-24, fo. 52.

${ }^{6}$ M. Romeris, Lietuvos konstitucinès teisès paskaitos (Vilnius, 1990), p. 224.
} 
former minister of education, close to the Christian Democrats in his ideology, was appointed the new editor and Matas Bagdonas, former director of the national news agency ELTA, supporting the nationalist ideology became his assistant and vice-deputy. ${ }^{7}$ Other employees of the pro-government paper remained as before.

The fact that the emerging Lithuanian authoritarian government or at least its leaders better than their opponents understood modern public relations campaigns (unusual for that period), saw their significance and particularly focused on formation of the international image is indicated by a few quite vivid moments. For example, the authorities took care that the elections of the new president in the Third Seimas were observed not only by local and foreign journalists but also by foreign diplomats specifically invited for the occasion to the houses of the Lithuanian parliament. If the information provided by the Lithuanian news agency ELTA and the press are to be trusted, 'comfortably seated in boxes for the the diplomats' in the Seimas, higher or lower ranking representatives of the diplomatic missions of Great Britain, Germany, Sweden, Norway, Estonia, Latvia and the USSR watched the procedure of electing Antanas Smetona president. ${ }^{8}$ The fact that the coup supporters managed with their actions and rhetoric to attract the interest of foreign countries at least for a while can be seen from the visit to Kaunas by Theodore Vaugham, the envoy of Great Britain to the Baltic States, from his permanent residence in Riga already on the day after the coup on 18 December. ${ }^{9}$ It is almost certain that this visit of the British envoy to Lithuania was not accidental and we tend to believe that it was directly associated with the events of 17 December in Kaunas and the wish of the British diplomacy to understand the situation as soon and as better as possible.

Just one day after the 'successful' campaign of the presidential elections in the Seimas, a public press conference of the new prime and minister of foreign affairs minister Voldemaras was held in the Ministry of Foreign Affairs. There the head of the government overly willingly and with certain familiarity and political demagogy

\footnotetext{
${ }^{7}$ Communication of the Lithuanian news agency ELTA of 18 December 1926, LNMMB RS, f. 157-24, fos. 47-48.

${ }^{8}$ Communication of the Lithuanian news Agency ELTA of 3 p.m. 19 December 1926, ibid., fo. 66 .

${ }^{9}$ Communication of the Lithuanian news Agency ELTA of 18 December 1926, ibid., fo. 46 .
} 
answered all the questions presented by journalists, demonstrated excellent skills of Western European languages and perhaps for the first time in the history of the Republic of Lithuania for the sake of popularity he tried to elicit the favour of the journalists and reporters participating at the press conference, treating them to coffee and biscuits generously. Apparently it was a cheap but wellthought gesture of the new regime in order to win over the media. Answering questions of the local and foreign journalists the prime minister and the minister of foreign affairs profusely explained to them that supposedly the major reasons for the political takeover overwhelming the country were purely 'in-country and of the national nature': the 'Bolshevist campaign' untamed by the former authorities, which was allegedly about to be used by Poland in order to dictate its will to Lithuania, ${ }^{10}$ as well as their 'corruption' 11 and the absolute dissatisfaction of the Lithuanian public with its government. In addition, Voldemaras highlighted for the journalists the principal directions of the domestic and foreign policy of the new government, namely protection of the private property and strengthening of the criminal law, the constitutional reform, promotion of relationships with neighbouring Germany, performance of the signed international

10 'Ministerio pirmininko pareiškimas spaudai', Lietuvos žinios, 21 Dec. 1926, p. 1; 'Ministerio Pirmininko ir Užsienio Reikalų Ministerio prof. A. Voldemaro pareiškimas spaudos atstovams', Lietuva, 21 Dec. 1926, p. 1.

11 At present it is complicated to say to what extent the accusations of the coup supporters to the former left-of-centre government concerning corruption were substantiated. However, some data lead to believe that such instances could actually occur. In the summer of 1926 as soon as M. Sleževičius became prime minister, he asked his Cabinet to 'find resources to compensate certain damages' he incurred working in the government. There is no data on how the Cabinet solved this subtle issue, but. Sleževičius working as a lawyer for many years was associated with a number of foreign firms doing business in Lithuania. His services were costly because Sleževičius was not only a lawyer, but also an influential politician. According to J. Paknys, the manager of the Bank of Lithuania, who worked at the bank for many years and accurately collected all the data about capital and financial flows of Lithuanian citizens, Sleževičius had accumulated steady amounts and together with Jodid, a representative of a German firm in Lithuania, had some real estate in Berlin, namely a 'large house'. The fact that Sleževičius had real estate in Berlin was not concealed by his son-in-law M. Mackevičius, but the latter claimed that the father-in-law had acquired a house in the capital of Germany by exchanging it to the manor in Klaipeda Region. Cf. Juozo Vaišnoro atsiminimai, Lithuanian Extraordinary Archive, Department of the LKP Documents (henceforth LYA LKPDS), f. 3377 ap. 51, b. 251, fo. 14.] 
treaties and continuity of the foreign policy. ${ }^{12}$ It is interesting to note that the new prime minister did not content with just mere oral answers to journalists. Shortly after the press conference the journalists were provided with the special communication of the government in French where the 'key' causes for the coup and accents of the new policy were emphasized once again.

Thus, a retrospective view at the first steps of the authoritarian government enables to conclude that the new authorities through the said campaigns of public relations wanted to speculatively counterbalance its relative political weakness in the country by exploiting the international factor. It seems that such ambitions of the emerging authoritarian government were not in vain. Although, unlike a similar event in neighbouring Poland six months ago, the coup in Lithuania was effected nearly overnight and without any in-country military-political clashes or complications of a more serious nature, the events of 17 December in Kaunas were subject to considerable reaction from abroad. Naturally, the media, political and diplomatic circles, various non-governmental institutions viewed the events of 17 December differently. At that time governments of Europe and the United States were mostly interested in the foreign policy of the new government and relationships with the closest neighbours, particularly Poland. Therefore, foreign journalists and public institutions tended to watch the domestic political situation following the coup and in general were interested in the fate of democracy in Lithuania.

The most expedite reaction to the political changes in Lithuania was presented by foreign radio stations and the press. However, the first news about the events of 17 December in Kaunas was not highly accurate and objective. Radio Prague was perhaps the first to break the news of the political changes in Lithuania to Central Europe. Referring to anonymous but reliable sources Radio Prague informed its listeners of the forced change of the government in Lithuania already in the morning of 17 December, in the 10 o'clock news. ${ }^{13}$ Some archival data allow claiming that such speedy reac-

12 'Ministerio pirmininko pareiškimas spaudai', Lietuvos žinios, 2 Dec. 1926, p. 1; 'Ministerio Pirmininko ir Užsienio Reikalų Ministerio prof. A. Voldemaro pareiškimas spaudos atstovams', Lietuva, 21 Dec. 1926, p. 1.

${ }^{13}$ Foreign wireless messages concerning the events of 17 December 1926 in Lithuania intercepted by the Lithuanian State Radiophone, LCVA, f. 929, ap. 3, b. 550 , fol. 1 . 
tion of Radio Prague was not a mere coincidence and was probably associated with the personal contacts and diplomatic activity of Jan Galia, the then envoy of Czechoslovakia to Lithuania*. The consul of Czechoslovakia to Lithuania maintained close relationships both with the local diplomatic corps and with the mission of the USSR in Kaunas, also with a number of Lithuanian politicians, representatives of the position and opposition, the military and various public activists. ${ }^{14}$

Furthermore, it seems interesting that apparently in all that rush the news editors of Radio Prague, while informing its listeners about the hottest events in Lithuania did not manage to avoid mistakes and jumbled a synchronic yet politically unequal constitutional change of the government in Latvia and the unconstitutional takeover effected by extreme rightists in Lithuania. Therefore the Czechoslovakian radio speaking of the events in the night of December 17 in Lithuania announced that

according to information from Kaunas, the railways are against the government and force had to be applied to make them perform their duties. Smetona refuses to be prime minister [...]. Kaunas parliament in night session with 52 votes for and 35 against expressed confidence in the revolutionary government. The labour parties of Lithuania launched an active fight against it. The province organizes a mutiny against Kaunas. ${ }^{15}$

Meanwhile in reality the Lithuanian Seimas in the night of December 17 did not and could not vote concerning the coup government because it was scattered by the pro-coup forces. It was the Latvian Parliament which after lengthy debates approved the leftist government at 1 a.m. on December 17; 52 deputies voted for, 35 against and two abstained. The German factions and right-wing Jews did not participate in the voting. Thus, a nearly synchronic change of the government in the night of December 17 in Kaunas and Riga confused Prague Radio mostly.

Somewhat later the German radio station Neues Deutchland informed its listeners of the coup in Lithuania, also claiming that

* It should be noted that during the coup d'état J. Galia was in Riga and returned to Kaunas most probably only in the afternoon of 17 December 1926.

${ }^{14}$ For greater detail about J. Galia's diplomatic activities in Lithuania at that period see A. Kasparavičius, 'Kauno ir Prahos politinio-diplomatinio bendradarbiavimo paradoksai 1922-1925 metais', Lietuvos istorijos metraštis 2003-1, pp. 120-125.

15 Foreign wireless messages concerning the events of 17 December 1926 in Lithuania intercepted by the Lithuanian State Radiophone, LCVA, f. 929, ap, 3, b. 550 , fo. 1 . 
Lithuanian labour unions supposedly '... protest against Kaunas dictatorship called a general strike'. ${ }^{16}$ The truth was that such information was unsubstantiated and rather an artifice of journalists. In the afternoon of the same day Radio Warsaw also aired the events in Kaunas. The Poles emphasized that Marshal Józef Piłsudski due to the sudden political changes in Lithuania met and 'discussed' them with the minister of foreign affairs, August Zaleski. According to Polish radio Zaleski expressed his position that the events of 17 December in Kaunas were exclusively a domestic issue of Lithuania and the government of Poland 'viewed them calmly'. ${ }^{17}$ However, it is interesting that irrespective of the supposedly indifferent manner of the southern neighbour of Lithuania the same radio announced that already in the afternoon of 18 December an extraordinary meeting of the Polish cabinet would be convened to discuss the events in Lithuania. ${ }^{18}$

On 18 December the unexpected political changes in Lithuania were announced by radio stations in Latvia, Great Britain, France, Italy, Belgium, Yugoslavia, Denmark and some other European states. For instance, Radio Oxford reviewing the events in Lithuania emphasized that the right-wing coup d'état was effected without spilling blood and '.. the well-informed circles believe that the revolution in Lithuania will not cause any complications'. ${ }^{19}$ Radio Paris was more critical in its assessment of the events in Lithuania. According to the French news, the 'socialist' government in Lithuania '... was overturned by the nationalist party' and former President Smetona was simply 'tempted by the power' once more. ${ }^{20}$ However, the radio doubted whether such radical changed would actually save the country from the deep domestic political crisis and help to deal with chronic international problems.

More considerate, broader and deeper comments of the events of 17 December 1926 in Kaunas were provided by other foreign press. The Latvian daily Jaunākās Ziņas described the coup d'état in Lithuania as '... a declaration of the fascist dictatorship'. The French press was more reserved. The French L'Oeuvre analysing causes for the coup and the political situation in Lithuania in no uncertain

\footnotetext{
16 Ibid.

17 Ibid.

18 Ibid.

19 Ibid., 9.

20 Ibid., fo. 10.
} 
terms stated that public opinion in Europe, given its 'generally bad reaction' to the conclusion of a neutrality and nonaggression treaty between Lithuania and the Soviet Union of 28 September $1926^{21}$ after the coup, could actually expect that the new government in any case would not be 'worse' than the old one. ${ }^{22}$ The Paris daily Le Matin commenting the controversial events in Lithuania was even more up-front. Stressing the fact that the nonaggression treaty made by the left-wing government with the USSR pushed Lithuania into 'the most severe political crisis', the paper wished that the new government '....would finally eliminate the red threat' and for the occasion printed pictures of the new 'leaders' of Lithuania Smetona and Voldemaras and overturned Prime Minister Sleževičius. ${ }^{23}$ Another equally popular French periodical Le Journal des Débats was not that optimistic about the policy of the new government and the future of the Lithuanian state. Viewing the events in Kaunas through the perspective of the controversial relations between Lithuania and Poland, which was so typical of the French at that period, the magazine made a meaningful note that Smetona already was the president of Lithuania once in 1919-1920 but that period was supposedly far from 'highly beneficial' to the Lithuanian-Polish relations.

Relatively benevolent comments of the 'revolutionary' change of the governments in Lithuania were provided in the daily Le Temps, supportive of the then French government. The periodical claiming the role of the pro-government paper already in the long editorial of 19 December wrote that Lithuania had actually a 'classical turnover' and the new president Smetona 'leaves a good impression'. ${ }^{24}$ The paper explained a speedy capitulation of the leftist government and establishment of the right-wing authorities in the country by the threat of a 'civil war' which supposedly forced the left-wing government to surrender so soon. Still Le Temps attempted a priori to push the authoritarian government of Smetona-Voldemaras to the

${ }^{21}$ More about the view of the Western states to the nonaggression treaty/pacts between Lithuania and the USSR of 28 September 1926 see A. Kasparavičius, Didysis X Lietuvos užsienio politikoje. 1926 metu Lietuvos ir Sovietu Sajungos nepuolimo sutarties sudarymo analize (Vilnius, 1996), pp. 288-318.

2218 Dec. 1926. A report to District Governor Svilas of 20 December 1926 by Vackus, the chief of the First Border Police Checkpoint of Ežerènai (Zarasai) District, LNMMB RS, f. 157-24, fo. 45.

${ }^{23}$ Ibid.

24 ‘Prancūzų oficiozas dèl ịvykių Lietuvoj’, Lietuva, 23 Dec. 1926, p. 1. 
'right' political direction and was very helpful to the new Lithuanian leaders to prompt that it was the time when ' $\ldots$ it was only wise to agree with Poland', because such agreement would both vitalize the country's economy and be useful politically since 'it would lay strong foundations for its political independence'. ${ }^{25}$ The radical political changes in Lithuania were more or less commented by other periodicals of France: Le Petit Parisien, L'Ére Nouvelle, L'Echo de Paris, etc. The truth is that far from all the comments were in favour of Lithuania. For instance, the influential L'Echo de Paris on 20 December published an article about Lithuania by Pertinax (real name: Géraud André), a popular French publicist of that time, where the events of 17 December 1926 in Kaunas were used creatively for the general anti-Lithuanian propaganda. In his review of the political history of Lithuania in the early twentieth century and referring to its undemocratic resolution on 17 December 1926, the author argued that recognition of the statehood of Lithuania had been a 'mistake' by the Western Allies because the 'Lithuanian nation does not exist' as it was a mere 'nation created' by the Russian imperial regime and, furthermore, the creation of the Lithuanian statehood was undermining geopolitical interests of the French ally in the east, i.e. Poland, by 'obstructing' the latter's natural way to the Baltic Sea. ${ }^{26}$

Comments concerning the events of late 1926 in Lithuania were also distinctive in the British prints. The Times, a pro-establishment paper, publishing the political map of Lithuania on 20 December wrote that the military-political coup in Lithuania was primarily conditioned by the 'pro-Soviet policy and indulgence to the communists' of the old left-wing government. In addition, the paper made a quite accurate remark that the coup 'was targeted against' Soviet Russia, the Lithuanian local communists and national minorities. ${ }^{27}$ The Daily Telegraph, irrespective of the previously mentioned public statements of Voldemaras to the media concerning continuity of the former foreign policy, was also quite brave in its prognosis that the true aim of the coup was to terminate the 'friendly relationships' of

25 'Kaip užsienių spauda aiškina perversmą Lietuvoje', Lietuvos žinios, 22 Dec. 1926, p. 2.

26 'Spaudos apžvalga', Lietuva, 23 Dec. 1926, p. 6.

27 'Times' žinios del perversmo Lietuvoj', Lietuva, 21 Dec. 1926, p. 1. 
Lithuania with the Soviet Union, which had been set by the leftwing government led by Sleževičius. ${ }^{28}$

Provided the Lithuanian news agency ELTA and Lithuanian correspondents abroad accurately collected information flowing from Western countries, we might claim that the anti-Soviet or anti-Russian nature of the December coup in Lithuania was more or less noted by the press of Sweden, Finland, Italy, Austria, Germany, Hungary and some Balkan countries. ${ }^{29}$ Some periodicals in their comments regarding events in Lithuania noted that the coup made Lithuania 'popular' and its name 'famous' in Europe and the first interview of the new prime minister and minister of foreign affairs to the press had left the foreigners with a quite 'good' impression. On the other hand, the press reviews were naturally different and often politically or ideologically slanted. At that time the Swedish right-wing daily Svenska Dagbladet wrote that the new Lithuanian president was 'quite an attractive person' and quoted positive notes by Smetona about the Swedish history and its former king, Karl X Gustav, whereas the Swedish Social Democratic publication Socialdemokraten referred to the coup effected in Kaunas as 'military' or even 'fascist' and claimed that entrenchment of the military or semi-military dictatorship in Lithuania would by no means strengthen peace at the borders of the Bolshevik Russia. ${ }^{30}$ As if continuing the idea of the Swedish journalists, the German Deutsche Allgemeine Zeitung at that time forecast that the coup could have a significant impact on the international development of Lithuania and eventually the region and bring rather various consequences because the foreign policy problems of Lithuania constituted a part of the 'interests' of its neighbours Poland, Germany and the USSR which in their turn could cause a collapse of sore international issues. ${ }^{31}$ The fact that the political coup in Lithuania could shake or even disrupt the international stability in the region was discussed by the German Berliner Tageblatt ${ }^{32}$ in the second half of December 1926. The paper predicted that upon establishment of the nationalists in the

\footnotetext{
28 'Otkliki zagranichnoi pechati', Pravda, 21 Dec. 1926, p. 3.

29 'Spaudos apžvalga', Lietuva, 21 Dec. 1926, p. 4.

${ }^{30}$ S. Pivoras, ' 1926 m. perversmas Lietuvoje Švedijos diplomatijos ir visuomenès akimis', Kultūros barai, 1998, no. 5, p. 74

31 'Posledniia izvestiia', Ekho, 22 Dec. 1926, p. 1; 'Kaip užsienių spauda aiškina perversmą Lietuvoje', Lietuvos žinios; 22 Dec. 1926, p. 2.

32 'Užsienio spauda apie Lietuvos Lenkijos karo galimybes', Lietuvos žinios, 22 Dec. 1926, p. 2.
} 
government in Poland and Lithuania, a conflict probability between the two countries was quite high.

The unconstitutional change of power in Lithuania received great attention from both foreign press and diplomatic circles or governments. The events of 17 December in Kaunas mostly startled the nearest neighbours of Lithuania, namely Poland and Latvia. Due to the coup in Lithuania, at the close of December 1926 Poland was the first to react and the Christmas holidays for the Polish patrols guarding the Lithuanian-Polish border were cancelled temporarily. ${ }^{33}$ Moreover, the Polish guards waited for their cavalry back-up. ${ }^{34}$ Yet according to the reports of the Lithuanian border police chiefs during the days of the coup the Polish not only strengthened their border but also told each other 'merrily' and 'willingly' that soon 'there would be porozumienie with Lithuania'. ${ }^{35}$ The benevolence of the Polish border guards to the Lithuanian border policemen during the days of the coup in Kaunas was then reported by chiefs of the First, Second and Third Border Checkpoints. For example, chief of the Second Checkpoint, J. Marčiūnas in his report wrote:

I hereby inform that it is all quiet behind the line of demarcation. On 19 December the Polish border guard battalion chief visited along the border and told the soldiers that they could speak to Lithuanian patrols and told them to treat the Lithuanian border police very politely because according to him we would be united soon ...The Polish border soldiers were merry and told everyone that they would be united with Lithuanians, abolish the line of demarcation and would go on the German border. ${ }^{36}$

The Polish authorities were less optimistic than the military. Irrespective of the information stated by the Polish media that Warsaw reacted to the coup d'état 'with great calmness', according to Józef Piłsudski himself the government of Poland monitored the events in

${ }^{33}$ A report to District Governor Svilas of 20 December 1926 by Vackus, the chief of the First Border Police Checkpoint of Ežerènai (Zarasai) District, LCVA, f. 929 , ap. 2, b. 995 , fo. 141.

${ }^{34}$ A report to District Governor Svilas of 21 December 1926 by Kazlauskas, the chief of the Third Border Police Checkpoint of Ežerenai (Zarasai) District, ibid., fo. 143 .

${ }^{35}$ A report to District Governor Svilas of 20 December 1926 by Vackus, the chief of the First Border Police Checkpoint of Ežerenai (Zarasai) District, ibid., fo. 141 .

${ }^{36}$ A report to District Governor Svilas of 21 December 1926 by Marčiūnas, the chief of the Second Border Police Checkpoint of Ežerenai (Zarasai) District, ibid., 1. 142. 
Lithuania very closely. ${ }^{37}$ This increased attention was probably associated with continuing suspicions of Warsaw that special agencies of Germany could have contributed to organisation of the coup d'état in Kaunas. ${ }^{38}$ The consequent situation in Lithuania was on 18 December discussed by the Polish government and on 19 December J. Piłsudski announced to the press that if Lithuania '.. showed an intention to attack the territory of Poland or began abusing the Lithuanian Poles', Poland would probably make a countermove and intervene. ${ }^{39}$ According to him in the opposite case, no complications should arise between the two countries.

The leader of Poland later continued to maintain practically the same position, i.e. that of reserved reaction and cautious optimism. In his 30 December interview to the press Piłsudski primarily stressed that he disapproved of tightening the Lithuanian-Polish border which would first of all harm the border residents of both countries and would be no actual political advantage from that. ${ }^{40}$ Discussing the situation in Lithuania after the right-wing coup and its political prospects Piłsudski also was not very optimistic. He referred to the situation in the neighbouring country as 'temporary' and admitted that it was often the case that a temporary state turned into a long-term phenomenon. Therefore, according to the Polish marshal 'the question whether the government of Voldemaras in Lithuania would become the lucky rescuer' that could change the future of the Lithuanian state positively would depend on the ability of that government to loosen its politics from overly 'unrealistic' and unfounded principles and formulae. ${ }^{41}$

Antons Balodis, the Latvian envoy extraordinary and minister plenipotentiary to Lithuania also reacted speedily to the events in Lithuania. The envoy already on 17 December informed his government of the military political coup in Kaunas. According to the diplomat, Bolshevik propaganda in Lithuania in the last weeks before the coup had been a great success and some people in Lithuania even

\footnotetext{
37 'Marshal Pilsudskii o Litve', Ekho, 31 Dec. 1926, p. 1

38 'Chto dumaiut i delaiut v Varshave', ibid., 21 Dec. 1926, p. 1; Z. Wroniak, Polska-Francja 1926-1932 (Poznań, 1971), p. 80.

39 'Chto dumaiut i delaiut v Varshave', ibid. 21 Dec. 1926, p. 1.

40 'Marshal Pilsudskii o Litve', ibid., 3 Dec. 1926, p. 1.

${ }^{41}$ Ibid.
} 
expected a communist putsch. ${ }^{42}$ Still further in his report we see that Balodis received the 'information' of the supposedly organized communist putsch from one of the coup ideologists, poet Liudas Gira. Further commenting the events in Kaunas Balodis wrote to his government that the city was subject to '... wide arrests of communists and supplies of arms were found', the leaders of the Social Democrats, namely Jeronimas Plečkaitis and Liuda Purénienè were arrested, who according to the diplomat in Lithuania were mostly 'famous for their extraordinary radicalism'. The 'insurrection' was effected with an approval of the largest Western states, Europe will 'accept it with a great satisfaction', the Latvian envoy predicted. Concluding his report the Latvian diplomat stated that as far as the coup struck communism in Lithuania, it 'served Latvia as well'. ${ }^{43}$ At the end of December due to the events in Lithuania Balodis was called up to Riga and there he presented to his government and the commission of the Ministry of Foreign Affairs a comprehensive report concerning the political changes in Lithuania: highlighted their causes and possible consequences. ${ }^{44}$

However, as has been mentioned on the same day the militarypolitical coup was effected in Lithuania by the right-wing forces a left-wing government was formed in Latvia where the key portfolios were divided among the Social Democrats. ${ }^{45}$ Thus, it is quite natural that the Latvian government of that time was not particularly happy about the turn of political events in Lithuania. Already in an interview of 21 December to the daily Jaunākās Zinas the Latvian minister of foreign affairs, Social Democrat Fēliks Cielēns diplomatically enough, yet with a certain irony noted:

'to the best of my belief, those escapades will remain domestic escapades in Lithuania. A known balance has formed in Eastern Europe, which under current circumstances would not and could not be shaken by any state. Therefore, the interior adventures of Lithuania would not cause misunderstandings abroad'. ${ }^{46}$

42 Extracts from the report of the Latvian envoy to Lithuania, J. Balodis, dated 17 Dec. 1926, concerning the coup in Lithuania, LYA LKPDS, f. 3377, ap. 58, b. 192 , fo. 124 .

43 Ibid.

${ }^{4}$ Z. Butkus, Lietuvos ir Latvijos santykiai 1919-1929 metais (Vilnius, 1993), p. 123 .

4518 Dec. 1926 ELTA communication through the State Radiophone, LNMMB RS, f. 157-24, fo. 51.

46 The report of the Lithuanian envoy to Latvia, Aukštuolis, dated 22 Dec. 1926, to the Lithuanian prime minister and minister of foreign affairs, Voldemaras, LCVA, f. 383 , ap. 7 , b. 659 , fo. 4 . 
The minister further emphasized that differences of political regimes should not hinder the cooperation of the Baltic States, and Riga would seek equally close relationships with Estonia, Finland and Lithuania. ${ }^{47}$ Still some data enable us to claim that the Latvian government was more interested in the fate of democracy in Lithuania. During Balodis' visit to Riga the Latvian minister of foreign affairs authorized the envoy to find out what were the actual prospects of the left-wing parties of Lithuania to regain the power. The diplomat promptly performed his assignment and already on 23 December reported to the minister that after various discussions with the leaders of the Lithuanian opposition parties and foreign diplomats it could be concluded that 'the Lithuanian Social Democrats have neither a strong organisation, nor enough intellectuals to take the fate of the state in their hands', thus it was unrealistic to expect their speedy return to the power. ${ }^{48}$

The reaction of the Latvian military reserve and veterans of the independence fights was different than the one of the Social Democratic government. Already in the morning of 18 December a telegram from the Central Board of the Latvian National Soldiers Society reached Kaunas with congratulations to the political leader of the coup, Antanas Smetona. The telegram read: 'The veterans of Latvia are sending to you and your brave army brotherly congratulations on your national deeds. Let your joys continue happening in the future as today. We are with you'. ${ }^{49}$

The organizers and agents of the December coup in Lithuania were congratulated on their 'success' not only by the veterans of the independence fights and nationalists of Latvia, but also by the Fascist People's Party of Sweden and Italian fascists. Greetings to Lithuanians on behalf Augusto Turati, the General Secretary of the Italian fascist party were passed by a 'friend of Mussolini' and a representative of the magazine Popolo d'Italia, Roberto Suster who at that time was on a visit to Kaunas. ${ }^{50}$ Moreover, the political changes in Lithuania interested not only the Italian fascists, but

${ }^{47}$ Ibid., fo. 3 .

48 Butkus, Lietuvos ir Latvijos santykiai, p. 123.

49 'To Smetona, the president of the Lithuanian state', a telegram of the Central Board of the Latvian National Soldiers Society, 18 Dec. 1926, LCVA, f. 929, ap. 3, b. 188 , fo. 261 .

50 'Spaudos apžvalga', Lietuva, 23 Dec.1926, p. 6. 
the king of that country, Vittorio Emanuele III. On 2 January 1927 the Lithuanian envoy to Italy, Valdemaras Čarneckis was granted a new-year audience with the Italian king and the monarch promptly enquired 'What is the news from Lithuania, has everything settled?' The king further wondered whether there really was a serious threat of a communistic turnover in Lithuania. ${ }^{51}$ Responding to the questions, the Lithuanian diplomat was forced to avoid straight answers. According to Čarneckis, Lithuania was a land of small land-owners and there were no objective conditions for the spread of communism. However, considering the geopolitical vicinity of the Soviet Union, Lithuania had to watch activities of communist emissaries closely and react timely. Otherwise, the state in such a geopolitical area simply would not exist. The Lithuanian envoy concluded his account to the king claiming that there was no direct danger for the communist regime in Lithuania, because 'the whole land would have opposed it', but there was a threat of communist attempts to effect their putsch in Lithuania and that way to 'provoke bloody battles and turmoil in the country' and provide an excuse for some other neighbours to 'intervene' in Lithuania. ${ }^{52}$ According to Carneckis, the coup d'état primarily prevented such development of events.

Estonia and Sweden met the unconstitutional change of governments in a reserved manner. On 18 December irrespective of the events in Lithuania, the Estonian Parliament calmly and without any official statements broke for the Christmas holidays. At the beginning of January 1927, after the holidays the Estonian ambassador to Sweden, Virgo, stated to Ignas Šeinius-Jurkūnas, the Lithuanian representative in that country: 'I see fellow-feeling for Lithuania is changing in our country. At first it was expected that the coup would bring an improvement of mutual relationships but Voldemaras' statement to the press about unpractical romanticism dampened the spirit ${ }^{6} .53$ Still the Estonian diplomat admitted that the coup '... was good promotion' for Lithuania in Europe. 'Our papers are still full of news from Lithuania. The coup prompted an interest in other aspects of

51 The secret communication of the Lithuanian envoy to Italy, Čarneckis, dated 3 Jan. 1927, to the minister of foreign affairs of Lithuania, LCVA, f. 383, ap. 7, b. 690 , fo. 27 .

52 Ibid., 1. 28.

53 The secret communication of the Lithuanian envoy to Sweden, I. ŠeiniusJurkūnas, dated 3 Jan. 1927, to the director of the Policy Department of the Ministry of Foreign Affairs of Lithuania; ibid., f. 383, ap. 7, b. 688, fo. 162. 
the Lithuanian life. It seems to me the same is happening in other countries. In general the coup is viewed approvingly abroad', the Estonian diplomat said to his Lithuanian colleague. ${ }^{54}$

As early as 19 December 1926 comprehensive reports of the unconstitutional change of governments effected in Lithuania were presented to their government by Torstens Unden, a Swedish envoy the Baltic States residing in Riga, and by E. Holmgren, a Swedish consul residing in Kaunas. The first of them stressed that the coup d'état had been ideologically prepared by the Christian Democrats and nationalists who attempted 'to make it as similar to a legal event as possible, therefore, no blood was spilled, although a few communists and socialists were arrested', and the second diplomat stated that during the days of the coup it was 'absolutely calm' in the capital of Lithuania and the officers satisfied with the Seimas' election of Smetona as president greeted the outcome noisily. ${ }^{55}$ It should be noted that the overturned government of the Peasant Popular Union and Social Democrats did not receive much sympathy from the Swedish diplomats. For instance, Unden in discussing the results achieved by the Peasant Popular Union and Social Democratic government and causes of the coup noted that the former left-wing authorities politically behaved in an amateurish and unprofessional manner. According to the Swedish diplomat, the Seimas directed by the Peasant Popular Union and Social Democrats in forcing events simply did not understand its political responsibility for the nation and the former government not only lacked abilities and education but also set high political ambitions and within a short time notably ruined relationships with the Catholic Church influential in the country, and the military. Moreover, the Swedish envoy with little respect referred to the former leaders, namely President Grinius, whom due to his cataract he called a 'half-blind honest village doctor without any outstanding qualities' and Prime Minister Sleževičius, whom he described as 'an untiring dancer in the official balls of Kaunas' and 'a vain bourgeois ... of mediocre abilities'. ${ }^{56}$

More distant neighbours of Lithuania, i.e. the Central and Western European states, reacted to the undemocratic political changes in Lithuania in a similar manner. In mid-January 1927 the Lithuanian

\footnotetext{
54 Ibid.

55 Pivoras, '1926 m. perversmas', p. 74.

56 Ibid., p. 73.
} 
envoy to Czechoslovakia, Dovas Zaunius informed Kaunas that recently he had discussed the mutual relationships between Lithuania and Czechoslovakia with the latter's minister of foreign affairs Edvard Beneš. According to the Lithuanian diplomat during their discussion Beneš noted that he considered the changes in Lithuania 'an internal matter of Lithuania' and did not see any need to discuss them in greater detail, also he did not think that they could in any negative way affect the relationships between Lithuania and Czechoslovakia. ${ }^{57}$

Sakalauskas, the secretary of the Permanent Mission of Lithuania at the League of Nations in Geneva informed the Ministry of Foreign Affairs of Lithuania that no complications had arisen in Switzerland due to the coup d'état effected by the right-wing forces and the embassy had not incurred any misunderstandings communicating with the Swiss authorities, there had been no public reproaching or protests of the society. ${ }^{58}$ The undemocratic seizure of the power in Lithuania did not cause any trouble with the local authorities for the Lithuanian embassies in Sweden and Denmark and the consulate in Norway. Admittedly on 3 January 1927 a protest concerning persecution of communists in Lithuania was stated to envoy Ignas Šeinius-Jurkūnas by representatives of the Swedish Communist Party. ${ }^{59}$ The Swedish communists even wanted to organize a public demonstration-picket in front of the Lithuanian embassy but after a brief dialogue with the Lithuanian diplomat and most probably due to the spectacular preparations by the Swedish police to block the protesters off the building, they abandoned the idea. ${ }^{60}$

On 3 January 1927 Ernestas Galvanauskas, the Lithuanian envoy to Great Britain, Belgium and the Netherlands informed Kaunas of the reaction of those countries to the coup. After discussions with politicians, diplomats, journalists and business people of those coun-

57 The secret communication of the Lithuanian envoy D. Zaunius, dated 26 Jan. 1927, to Voldemaras, Ibid., b. 691, fo. 17.

58 Secret communication of Sakalauskas, the first secretary of the Lithuanian Mission in Switzerland, dated 1 Feb. 1927, no. 104, to the Policy Department of the Ministry of Foreign Affairs of Lithuania, ibid., b. 695, fo. 43.

59 The secret communication of the Lithuanian envoy to Sweden, I.ŠeiniusJurkūnas, dated 12 Jan. 1927, to Bronius Kazys Balutis, the director of the Policy Department of the Ministry of Foreign Affairs of Lithuania, Ibid., b. 688, fo. 164 .

${ }^{60}$ Ibid. 
tries Galvanauskas wrote from London to Kaunas: 'The Ministry of Foreign Affairs [of the Netherlands] showed a live interest and I have been asked many questions about our political coup. Our slogan "Fight against Bolshevism" here as well as in London was assessed positively. The fight against Bolshevism is popular here'. ${ }^{61}$ Moreover, according to the diplomat the director of the Policy Department of the Dutch Ministry of Foreign Affairs even told him in private that 'You have set a good example for the others'. ${ }^{62}$

An active interest of Great Britain in the events of 17 December in Lithuania can be seen from even two successive visits of Theodore Vaugham, the envoy of that country, to Kaunas in a short period of time. On the first days of January 1927 for the second time within mere two weeks the British diplomat came from Riga to the provisional capital of Lithuania and met with Voldemaras and was also seen by Smetona. Since the official minutes were not taken during those meetings we can only judge their content from secondary documents. As it can be seen from reports of the Lithuanian secret police, the agents of which apparently in an off-the-record manner 'participated' in the meeting of the prime minister with Vaugham, the British diplomacy was mostly interested in the geopolitical orientation of the new government and relationships with its southern neighbour Poland. Based on the data of the Lithuanian secret police, Vaugham at the meeting told Voldemaras that London by all means supported the new government of Lithuania, recognized its rights to Vilnius and was even ready to exert political 'pressure' on Warsaw concerning that matter. ${ }^{63}$ However, Lithuania could expect such political support from London only in case Lithuania agreed to establish a close political-economic union with Poland. According to the report of a Lithuanian secret police officer, Voldemaras received this offer of the British envoy rather coolly and did not express his clear opinion on the issue. ${ }^{64}$

${ }^{61}$ The secret communication of the Lithuanian envoy to Great Britain, Belgium and the Netherlands, E. Galvanauskas, dated 3 Jan. 1927, to Voldemaras, Ibid., b. 693 , fo. 32 .

62 Ibid.

${ }^{63}$ The 'top-secret' communication of an agent of the Lithuanian Political Police, dated 2 Jan. 1927, to the chief of the Political Police, LYA LKPDS, f. 77. b. 42 . fo. 10 .

64 Ibid. 
On those days the British envoy was also seen by Smetona. However, no extensive data could be found concerning that meeting. Brief press announcements indicate that the political-economic relationships and the foreign policy priorities of the new government were discussed. ${ }^{65}$

Still the unconstitutional change of the power and formation of the undemocratic regime in Lithuania caused various reactions in this citadel of democracy called Great Britain. The Lithuanian envoy, Galvanauskas in London encountered not only with approval of the anticommunist ambitions of the new government of Lithuania. On 31 December the Manchester Guardian referred to the domestic policy of the new regime as simply 'reactionary' and 'terrorist'. ${ }^{66}$ On 3 January 1927 the British Section of the International War Prisoners Aid Association handed Galvanauskas a stern letter of protest also noting the 'concern' of that organization for persecution of workers, arrests and killings in Lithuania. According to the protest authors, the regime resulting from the December coup was much more brutal than the one prevailing in the Republic of Lithuania in 1919-1923 when a number of workers were imprisoned and sentenced to death. ${ }^{67}$ The letter of protest ended in a demand for the government of Lithuania to free all political prisoners 'immediately'. Answering the protest on 5 January the Lithuanian envoy informed the said organization that the Lithuanian government was forced to 'punish' a few persons 'for the sake of security interests of the state' and those campaigns of the government could by no means be considered as directed against the working class of Lithuania. ${ }^{68}$

On 15 February due to the undemocratic events in Lithuania, namely the persecution of labour organizations, the embassy of Lithuania in London was visited by a delegation of the Council of Great Britain Trade Unions: G. Hicks, W.L. Citrine, B. Tillett, E.L. Poulton, A. Purcell, A.A.H. Findlay and W.J. Balton. The delegates of the organization representing interests of over 5 million British work-

65 'Politiškos naujienos', Lietuvis, 12 Jan. 1927, p. 1.

${ }^{66}$ A letter of protest of the International War Prisoners Aid Association (the British Section), dated 3 Jan. 1927, to the Lithuanian envoy to Great Britain, E. Galvanauskas, LCVA, f. 383, ap. 7, b. 698, fo. 167.

67 Ibid.

${ }^{68}$ A letter of the Lithuanian envoy to Great Britain, E. Galvanauskas to the International War Prisoners Aid Association (the British Section) dated 5 Jan.1927 (a copy), ibid., fo. 168 . 
ers were 'privately' seen by Galvanauskas. It is interesting to note that according to the Lithuanian diplomat the delegates promptly assured him that they 'were not interested' in the situation and fate of communist organizations in Lithuania. The representatives of the British trade unions did not submit any official protests or demands to the envoy of Lithuania, only (after an explanation that they 'did not intend to interfere' with the domestic matters of Lithuania) stated that they would like to clarify officially 'the negative news they received' about the position of trade unions in Lithuania. ${ }^{69}$

Reporting of the said campaigns to the Lithuanian Ministry of Foreign Affairs, Galvanauskas stressed that he was trying to develop working relationships with the organizations 'concerned' about the issues of Lithuania and the press supporting such organizations and to inform them of the events in Lithuania as objectively as possible. Still discussing the questions raised by some British protesters concerning the situation in Lithuania, the diplomat clearly noted that apparently 'they received fantastic reports from various unchecked sources' and in this respect most likely there was some actions against Lithuania by 'Moscow Comintern'. ${ }^{70}$

It should be noted that such assumptions and reasoning of the Lithuanian diplomat were very close to the truth. On 30 December 1926 the Political Bureau of the Central Committee of the Communist Party adopted a special directive concerning the events in Lithuania. Its second clause indicated that in order to regain the Lithuanian regime favourable to Moscow it was 'necessary' to organize meetings and adopt public protest resolutions. Moreover, the Kremlin directive provided that it was necessary 'to strengthen pressures abroad': 'where possible, to organize demonstrations and send special delegations to missions of Lithuania abroad'71 against the new government in Lithuania. We did not manage to obtain data on how the Kremlin emissaries succeeded in implementing such directives. However, considering the fact that right in 1926 mass coalminer strikes were organized in Great Britain, which were

${ }^{69}$ The secret communication of E. Galvanauskas, dated 15 Feb. 1927, to Voldemaras, ibid., fo. 148 .

${ }^{70}$ The secret communication of Galvanauskas, dated 5 Jan. 1927, to Voldemaras, ibid., fo. 166 .

${ }^{71}$ Minutes No.75 of a meeting of the Political Bureau of the Central Committee of VKP(b) dated 30 Dec. 1926 (Extraordinary dossier No. 57), Centre for Preservation and Research of Modern Historical Documents of Russia (henceforth RNIDSTC), f. 17 , ap. 162 , b. 4 , fo. 35 . 
substantially regularly financially supported by the Kremlin in se$\operatorname{cret}^{72}$ - sometimes a one-time relief for the strikers was a million roubles or more ${ }^{73}$ - a scenario that some British trade unions or their individual activists could be under certain influence of Moscow and in one way or another (not necessarily directly) contribute to Kremlin initiatives against Lithuania is quite possible. On the other hand, it would be unreasonable to consider the protests launched in Great Britain at the close of 1926 - in early 1927 against the undemocratic regime in Lithuania only Kremlin initiatives, because in the country with such deep democratic traditions protests of the public or individual institutions against any antidemocratic manifestations were an eminent and natural phenomenon undemanding any suggestions from outside.

News of the political turnover in Lithuania reached the United States of America soon enough. Already on 20 December The New York Times in its article 'Lithuania Changes Fronts' reviewed the new government of the country essentially positively only with some regrets concerning its anti-Polish position ${ }^{74}$. On the same 20 December Voldemaras wired Fredrick Coleman, a representative of the US for the Baltic States residing in Riga, a telegram informing of his appointment the minister of foreign affairs and expressed a wish to maintain strong relationships between the countries in the future. Shortly Voldemaras received a private letter-response from F. Coleman with greetings to the new authorities and best regards. In addition, Coleman assured the prime minister of Lithuania that the new government could be calm - he would approve both mutual cooperation and other common goals in Europe. ${ }^{75}$ Summarising the reaction of the US authorities to the events of 17 December 1926 we might agree with the assumptions that the policy pursued by the Peasant Popular Union and Social Democrats government in the summer-autumn of 1926 was essentially inconvenient for the administration of the US, thus in terms of the right-wing coup in Kaunas

\footnotetext{
72 Minutes No.41 of a meeting of the Political Bureau of the Central Committee of VKP(b) dated 17 July 1926 (Extraordinary dossier No. 30); Minutes No. 43 of a meeting of the Political Bureau of the Central Committee of VKP(b) dated 29 July 1926 (Extraordinary dossier No. 31), ibid., b. 3, fos. 97-98.

${ }^{73}$ Minutes No.39 of a meeting of the Political Bureau of the Central Committee of VKP(b) dated 8 July 1926 (Extraordinary dossier No. 29), ibid., fo. 96.

74 'Spaudos apžvalga', Lietuva, 12 Jan. 1927, p. 1.

75 J. Skirius, Lietuvos užatlantès diplomatija 1918-1929 metais (Vilnius, 1995), p. 98 .
} 
they primarily linked it with their hopes to withdraw Kaunas from the suspicious political-economic cooperation with Moscow. ${ }^{76}$

Later with strengthening the authoritarian government of Lithuania the United States consul in Kaunas prepared a comprehensive report to the State Department concerning political priorities and figures of the new government describing in detail the first persons of the state President Smetona and Prime Minister and the Minister of Foreign Affairs Augustinas Voldemaras. The American wrote to his superiors about the new president of Lithuania:

... a man of a reserved position with a clear anti-Polish orientation and a certain fellow-feeling for Russia as well as Germany; that liking was particularly apparent when he was still a journalist... As a personality he is strictly respected by everyone /even the opposition/. In terms of the domestic policy he is a Catholic but not a clericalist and also an opponent of the agrarian reform. He is under an obvious influence of Prime Minister Prof. Voldemaras. He is very closely associated with the army, which actually made him president for the second time. ...As a person and not a politician, he is mostly engaged in scholarly matters in the field of ethics which is evidenced by a number of his articles and brochures. He does not look for his own profit and is undoubtedly a great patriot. ${ }^{77}$

The American diplomat made an equally accurate and colourful description of the new Prime Minister and the Minister of Foreign Affairs Voldemaras:

A person of very good education and with a university degree, of high learning and a simply phenomenal memory, a historian, lawyer, linguist, almost fluently speaks all the major European languages and also has knowledge of Greek and Latin. As a personality he is eccentric, self-confident, does not delegate anything to his colleagues; he believes he has a calling to rule the country; extremely hardworking. He is of the opinion that everything that had been done or adopted by the former governments, to put it shortly in his absence, are no more suitable and needs to be either cancelled or amended as can be seen from the radical referendum. He is a clear opponent of the agrarian reform. He is of rather unsettled character, could be pleasant, likable and polite, but also very strict, even rude. ...Currently he is the actual leader of the country. In terms of the mind composition he is more of an analyst than a synthetist and this could explain inconsistency in his lectures and state acts for example, the referendum. ${ }^{78}$

76 Ibid.

77 Žinios iš Konsulatu - supplement of The Informational Bulletin (Žiniu biuletenis) of the Lithuanian Criminal Police, no. 83, 2 Sept. 1927, LCVA, f. 923, ap. 1, b. 504, fo. 354 .

${ }^{78}$ Ibid., 1. 355. 
Germany, the western neighbour of Lithuania, responded calmly to the military-political coup in Kaunas. The government of Germany was mostly interested in the policy the new authorities would pursue regarding the Klaipeda Region and whether rights of national minorities, naturally first of all the rights of the Lithuanian Germans or those who consider themselves as such, would not be restricted. Admittedly at first Berlin had suspicions that the coup was effected with the Polish assistance but soon abandoned that idea because the German envoy to Lithuania Hans Ludwig Morath saw that the coup was merely an outcome of the activities of the local radical military. ${ }^{79}$

Different reactions to the political changes in Lithuania could be observed in France. The press and liberal, democratically-minded activists of that country reviewed the repressions of the authoritarian government against communists particularly negatively. Shooting of four activists of the Lithuanian Communist Party on 26 December 1926 was understood in France only as disposing of political opponents. Reflecting on the feeling of the French authorities and the public the Lithuanian envoy, Petras Klimas in his 28 December report from Paris to Kaunas emphasized that the court-martial sentence left 'an extremely uncomfortable impression' 80 for both the French left and right. Around that time the French also suspected that the coup in Kaunas could have been inspired by the German or Soviet special agencies acting against interests of Poland in the region and for some time there were even fears that the new government of Lithuania supposedly affected by such suggestions would seek adverse campaigns against the local Polish minority or regarding the Vilnius Region in general. ${ }^{81}$ The French consulate in Kaunas even had suspicions and spread the news that the new government using the paramilitary Riflemen Union of Lithuania was allegedly secretly preparing a march to Vilnius. The Lithuanian Ministry of Foreign Affairs only in early January 1927 managed to dispel such rumours

${ }^{79}$ M. Hellman, 'Der Staatsstreich von 1926 in Litauen. Verlauf und Hintergrunde', Jahrbücher für Geschichte Osteuropas, 1980, Bd. 28, pp. 229-230.

${ }^{80}$ A. Kasperavičius, '1925-1929 m. tarptautinès Lietuvos politikos klausimai', Lietuvos istorijos studijos, 1996, vol. 3, pp. 96-97.

81 The enciphered telegram of the director of the Policy Department of the Ministry of Foreign Affairs of Lithuania, B.K. Balutis, dated 6 Jan. 1927, to the Lithuanian envoys to Great Britain, France, Italy, Germany, Czechoslovakia and Latvia, LCVA, f. 383, ap. 7, b. 711, fo. 249. 
and suspicions spread by the French diplomacy when diplomats of France, Great Britain and Italy were offered to visit the line of demarcation between Lithuania and Poland and see for themselves the peaceful intentions of Lithuania. ${ }^{82}$ Irrespective of the fact that that the Lithuanian Ministry of Foreign Affairs was even ready to bring foreign representatives and journalists to the 'military zone' by the Ministry transport, the French, Italian and British diplomats turned down the invitation for the mid-winter excursion to the southeast Lithuania. Soon enough the said accusations for Lithuania concerning the alleged venturesome foreign policy were forgotten.

However, already in mid-January 1927 the political climate in Paris regarding Lithuania became milder and on that occasion Klimas wrote expressively to Kaunas: 'I have noticed that the issue of Lithuania entered the centre of urgent problems of the East not only from the Quai d'Orsay, where it was mentioned to me by the director of the European department, but also from a number of discussions on various levels: journalists, deputies, bankers'. ${ }^{83}$ The interest in "post-coup" Lithuania in Paris did not lessen for a while. On 19 January Aristide Briand, the French minister of foreign affairs, informed the Commission of Foreign Affairs of the situation in Lithuania and its political perspectives. According to Klimas, the minister was mostly asked '....about causes and consequences of the coup d'état of 17 December in terms of the general PolishFrench security'. ${ }^{84}$ In February - March 1927 Klimas informed the government several times that activities of the new government in Lithuania were viewed positively in Paris and there were even tentative hopes for the resolution of the Lithuanian - Polish dispute. According to the Lithuanian diplomat '...in general official circles in Paris let a warm wind towards Lithuania'85 which is why the political positions of Lithuania in France and in Western Europe were only strengthening. ${ }^{86}$

82 Ibid.

83 The secret communication of the Lithuanian envoy to France, P. Klimas, dated 20 Jan. 1927, to the minister of foreign affairs of Lithuania, A. Voldemaras, ibid., b. 692 , fo. 89 .

${ }^{84}$ Ibid., b. 692, fo. 91.

${ }^{85}$ The secret communication of the Lithuanian envoy to France, P. Klimas, dated 23 Feb. 1927, to A. Voldemaras, ibid., fo. 71.

${ }^{86}$ The secret communication of Klimas, dated 26 Feb. 1927, to Voldemaras, ibid., fo. 61 . 
The fact that within just a few months after the coup the French authorities gradually accepted the political changes in Lithuania and even associated with the new regime their own political-diplomatic hopes seems to be proven not only by more frequent articles favourable to Lithuania in early spring 1927 in the French press, for instance, Le Temps ${ }^{87}$, but by the increased level of diplomatic representation of France in Lithuania. The former chargé d'affaires of France in Kaunas was replaced by a diplomat of a higher rank, namely, the envoy extraordinary and minister plenipotentiary, Gabrielle Puaux. ${ }^{88}$ Considering the fact that only a few diplomats of that relatively high rank were residing in the provisional capital of Lithuania, such an appointment undoubtedly pleased the ego of the authoritarian government of Lithuania and also served as a certain symbol of international recognition. ${ }^{89}$ Moreover, one more player of the great concert of the European policy, i.e. Italy, made a similar move.

Summarising the results of the study several more significant moments may be distinguished. On the one hand, the majority of liberal democratic governments in European states and the administration of the United States viewed the events of 17 December 1926 from a geopolitical angle rather than assessing the progress of Lithuanian domestic policy. Therefore, they had at least a reserved and unopposed, if not favourable, view of the events of the 17 December 1926 in Lithuania, since they primarily associated the coming to power of the new authorities with a decline of Soviet political influence both in Lithuania and in the entire north-eastern Baltic Region and saw a potential opportunity to eliminate the continued Lithuanian - Polish conflict. Furthermore, in terms of the international conjuncture of

87 The secret communication of Klimas, dated 23 Feb. 1927, to Voldemaras, ibid., 1. 71; the secret communication of Klimas, dated 26 Apr. 1927, to Voldemaras, ibid. fo. 39 .

${ }^{88}$ Č. Laurinavičius, 'Augustino Voldemaro užsienio politika ir Lietuvos geopolitika 1927-1929 m.’, Politika ir diplomatija (Kaunas, 1997), p. 192.

${ }^{89}$ Regrettably, in the mid-1920s the Kaunas diplomatic corps was not very bright. Diplomats with a rank of ambassadors did not reside in Lithuania at that time. It was the privilege of only the 'larger' states. Only four or five foreign diplomats with the rank of an envoy extraordinary and minister plenipotentiary permanently resided in the provisional capital of Lithuania that period. According to the usual practice, the largest foreign states would often appoint one high-ranking diplomat for all the three Baltic States, an envoy extraordinary and minister plenipotentiary. No wonder that sometimes intensive competition was going on among Kaunas, Riga and Tallinn for the right and honour to receive this foreign guest, but due to its geographical position (and not only that) this fight was won mostly by Riga. 
the period, the return of the Christian Democrats and nationalists to power in Lithuania allowed the so-called architects of high politics to think about strengthening of the anti-Bolshevik front of democracies against the highly unpredictable foreign policy of the Soviet Union. The subsequent development of political events in Lithuania and Europe showed how reasonable such hopes were and whether they would come true. On the other hand, it should be noted that the public, labour professional organisations and a part of the media in a number of foreign democracies were critical about the unconstitutional change of the government in Lithuania and the dictatorial domestic policy of the government formed on authoritarian grounds. However, assessing the international reaction from this perspective one should bear in mind that some of the campaigns in the West directed against the authoritarian government of Lithuania were inspired by the Soviet Union and its puppet Third International via its representative offices and agents. Thirdly, in the eyes of liberal and democratic citizens or societies of Western Europe the December coup d'état impaired the international prestige of Lithuania since it prompted doubts about the democratic traditions of the young state, and the maturity of its social and political culture as well as prospects of maintaining its statehood.

Author details:

Dr Algimantas Kasparavičius studies the international relations, political and diplomatic history of Lithuania and Europe of the twentieth century.

Address: Department of the Twentieth-Century History of Lithuania, Lithuanian Institute of History, Kražių 5, 01108 Vilnius, Lithuania

Email: algimantas.kasparavicius@gmail.com

\section{VAKARŲ ŠALIŲ POŽIŪRIS I 1926 METŲ PERVERSMĄ LIETUVOJE \\ Santrauka}

\section{ALGIMANTAS KASPARAVIČIUS}

1926 m. gruodžio 17 d. perversmo analizè ir vertinimas lietuvių istoriografijoje daugeliu aspektų tebėra gana aktuali ir kontroversiška problema. Po perversmo susiformavęs autoritarinis režimas istorinèje literatūroje buvo apibūdinamas ir vertinamas įvairiai, tačiau toli gražu ne visuomet argumentuotai. Pernelyg pakilus požiūris i̇ perversmą dažniausiai būdingas kai kuriems lietuvių išeivijos istoriniams ir paraistoriniams tekstams. Subjektyvios, ideologizuotos perversmo kritikos ar apologetikos nestokojo gana gausi memuarinè literatūra. Sovietmečiu šis istorinis 
Ł̇vykis buvo dar labiau ideologizuojamas ir dažniausiai nepagristai, neargumentuotai interpretuojamas kaip profašistinis ar net fašistinis. Kita vertus, tuo pačiu metu dalis patriotiškai ir antisovietiškai nusiteikusios lietuvių visuomenès neviešai prieštaravo tokioms totalitarinès valdžios kontroliuojamų istorikų vertinimų tendencijoms ir 1926 m. gruodžio 17-osios perversmą miglotai bandẻ įvilkti ị patrauklesnị nacionalizmo rūbą bei tam tikru aspektu implikuoti i pasipriešinimo sovietizacijai heroiką. Tokiomis aplinkybėmis lietuvių savimonèje formavosi gerokai nevienareikšmis perversmo vaizdinys. Taigi publikuojamo straipsnio tikslas (nesistengiant vienu ypu ir iškart atsakyti $\mathfrak{i}$ visus su minima problematika susijusius klausimus) pažvelgti i problemą kiek neiprastu aspektu ir iš atokiau: išnagrinèti tiesiogiai nesuinteresuotu užsienio šalių politinę-diplomatinę reakciją i perversmą Lietuvoje.

Apibendrinant atlikto tyrimo rezultatus galima reziumuoti keletą reikšmingesnių momentų. Dauguma Europos valstybių demokratinių vyriausybių ir Jungtinių Amerikos Valstijų administracija 1926 m. gruodžio 17 d. įvykius Lietuvoje vertino, jeigu ne palankiai, tai bent jau santūriai ir nepriešiškai, nes su naujosios valdžios atėjimu pirmiausia siejo Sovietu Sajungos politinès itakos susilpnejjimą ne tik Lietuvoje, bet ir visame regione bei ižvelgė atsiveriančią perspektyvą pašalinti isisenejjusi lietuvių-lenkų tarpusavio konfliktą, kuris aiškiai trukdẻ Europos pacifikacijai. Be to, žvelgiant iš to meto tarptautinès konjunktūros, krikščioniškosios demokratijos bei nacionalistų sugrižimas ị valdžią Lietuvoje vadinamosios didžiosios politikos architektams (pirmiausia, žinia, dešiniujų pažiūrų) kurį laiką leido galvoti apie liberalių demokratijų fronto sustiprinimą prieš sunkiai prognozuojamą SSRS. Kiek tokie lūkesčiai buvo pagrịsti ir ar pasitvirtino, parodè vėlesnè politinių îvykių raida Lietuvoje ir Europoje. Kita vertus, reikia pabrežti, jog daugelio užsienio demokratinių šalių visuomeninès, darbininkų profesinès organizacijos bei dalis žiniasklaidos kritiškai vertino nekonstitucinį vyriausybių pasikeitimą Lietuvoje ir naujosios, autoritariniais pagrindais besiformuojančios valdžios diktatūrinę vidaus politiką. Tačiau tokiu aspektu vertinant tarptautinę reakciją i̇ perversmą nedera pamiršti, jog dali prieš autoritarinę Lietuvos valdžią nukreiptų akcijų Vakaruose inspiravo Sovietų Sajunga bei jos kontroliuojamas III komunistų internacionalas per savo atstovybes ir agentūrą. Be to, neabejotina, kad liberaliai bei demokratiškai nusiteikusių Vakaru Europos piliečių ar visuomenių akyse 1926 m. gruodžio 17-osios perversmas pakenkẻ Lietuvos tarptautiniam prestižui, nes skatino abejoti jaunos valstybès demokratinėmis tradicijomis, socialine ir politinès kultūros branda bei valstybingumo išlaikymo perspektyvomis. 